https://doi.org/10.17816/MAJ191S194-96

\title{
NEUROIMMUNE PATTERN IN THE COMORBIDITY BETWEEN DEPRESSION AND ALCOHOL USE DISORDER
}

\author{
T.I. Nevidimova ${ }^{1}$, T.V. Davydova ${ }^{2}$, L.A. Vetrile ${ }^{2}$, D.N. Savochkina ${ }^{1}$, I.A. Zakharova ${ }^{2}$, S. Galkin ${ }^{1}$ \\ ${ }^{1}$ Mental Health Research Institute, Tomsk; \\ ${ }^{2}$ Institute of General Pathology and Pathophysiology, Moscow
}

\section{НЕЙРОИММУННАЯ ХАРАКТЕРИСТИКА КОМОРБИДНОСТИ ДЕПРЕССИИ И АЛКОГОЛИЗМА}

\author{
Т.И. Невидимова ${ }^{1}$, Т.В. Давыдова ${ }^{2}$, Л.А. Ветрилэ ${ }^{2}$ Д.Н. Савочкина ${ }^{1}$, \\ И.А. Захарова ${ }^{2}$, С.А. Галкин ${ }^{1}$ \\ ${ }^{1}$ НИИ психического здоровья Томского НИМЦ РАН, Томск; \\ ${ }^{2}$ НИИ общей патологии и патофизиологии, Москва
}

nevidimova@yandex.ru

The aim of the study is to search for biomarkers of risk and prevention of the formation of alcohol dependence on the background of depression. Antibodies are evaluated for a number of neurotransmitters, the information content of which is confirmed by preliminary studies. Materials and methods. Autoantibodies to dopamine, norepinephrine, 5-hydroxytryptamine, glutamate, gamma-aminobutyric acid were determined by ELISA in 60 controls and patients with depression and alcohol use disorder (AUD). Results. The level of antibodies to all studied neurotransmitters decreases with depression, especially complicated by alcoholism. An exception is the level of antibodies to serotonin, which increases with AUD and depression combined with AUD. Conclusion. It is assumed that this type of reaction may be a biomarker of the risk of alcoholism in depression.

Keywords: depression; alcohol use disorder; antibodies to neurotransmitters.

Целью исследования является поиск биомаркеров риска и превенции формирования алкогольной зависимости на фоне депрессии. Оцениваются антитела к ряду нейромедиаторов, информативность которых подтверждена предварительными исследованиями. Материалы и методы. Антитела к дофамину, норадреналину, серотонину, глутамату, гамма-аминомасляной кислоте определены в пробах крови 60 человек - контрольных лиц, пациентов с депрессией и алкоголизмом. Результаты. Уровень антител ко всем изученным нейротрансмиттерам снижается при депрессии, особенно осложненной алкоголизмом. Исключением является уровень антител к серотонину, который нарастает при алкоголизме и депрессии, сочетанной с алкоголизмом. Заключение. Предполагается, что подобный тип реакции может быть биомаркером риска формирования алкоголизма при депрессии.

Ключевые слова: депрессия; алкоголизм; антитела к нейромедиаторам.

Introduction. The combination of addictive and affective disorders is extremely high and occurs in almost half of the cases. The polymorphism of comorbid disorders is due to complex biological mechanisms associated with the dysregulation of neurotransmitter systems and the insufficient effect of selective serotonin reuptake inhibitors on anhedonia, a key symptom of depression and addiction disorders. The combination of affective and addictive disorders reduces the effectiveness of treatment. The search for the association of depression with addiction is relevant. The possibility of increased production of autoantibodies to dopamine, serotonin, norepinephrine, glutamate and opioid receptors is indicated for various forms of drug dependence and depressive disorders. A possible common pathogenetic mechanism that ensures the comorbidity of the addiction syndrome and affective disorders is the reward system [1-4].

Objective: to search for biomarkers of risk and prevent the formation of dependence on the background of depression. As the main biomarkers, antibodies to a number of neurotransmitters have been studied, the information content of which is confirmed by preliminary studies.

Materials and methods. Blood samples from 60 people were studied (16 controls, 18 depression, 18 alcohol use disorder (AUD), 8 comorbid depression and AUD). Autoantibodies to dopamine (DA), norepinephrine (NE), serotonin or 5-hydroxytryptamine (5-HT), glutamate (Glu), gamma-aminobutyric acid (GABA) were determined by ELISA

Results and discussion. The results are shown in the figure 1 .

Almost all types of antibodies revealed a general pattern. With alcoholism, their level decreases slightly, with depression decreases significantly, with comorbid pathology decreases most pronounced. The exception is the level of antibodies to 5-HT. It is reduced in depression, in alcoholism and comorbidity it is increased. The most likely explanation is a serotonin deficien- 


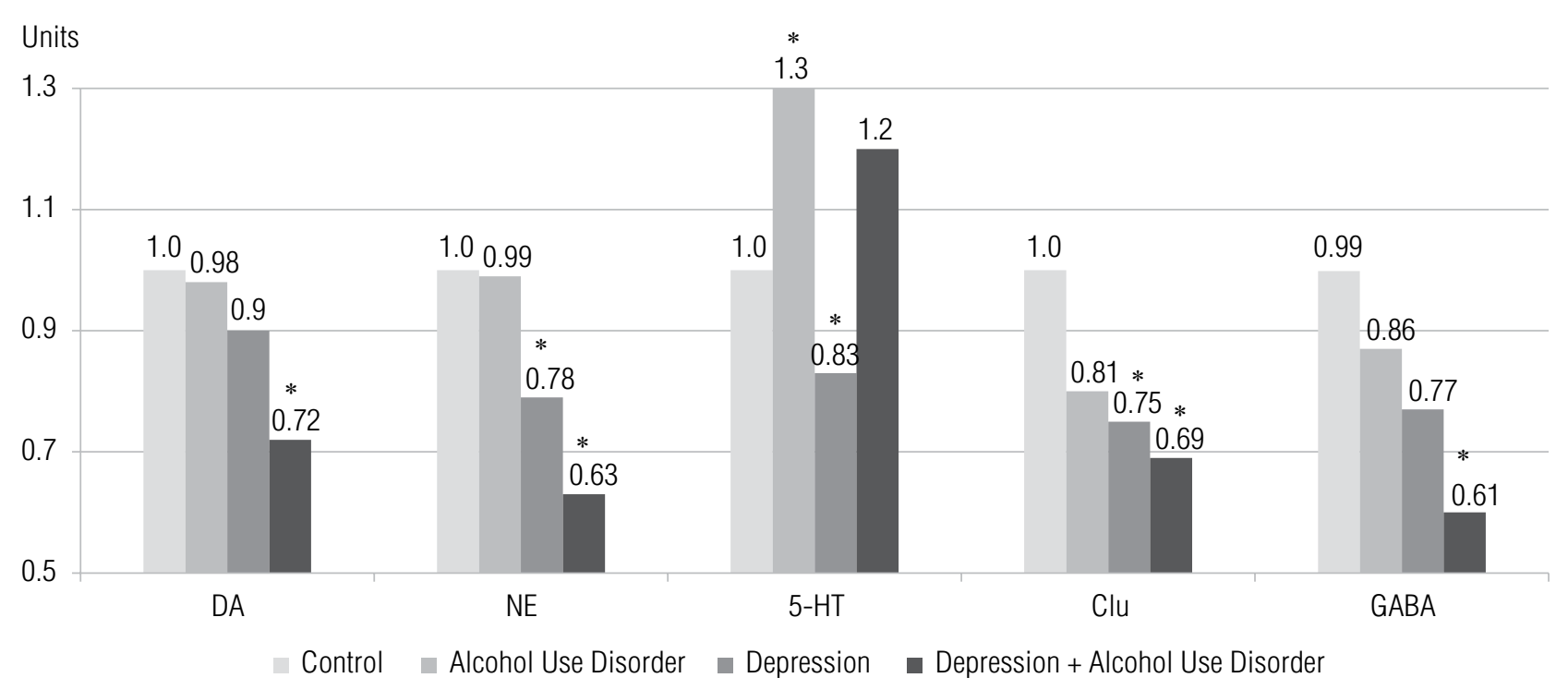

Fig. 1. Average levels of autoantibodies to neurotransmitters in depression and alcohol use disorder. The ordinate axis is the level of antibodies (in units) to dopamine (DA), norepinephrine (NE), serotonin or 5-hydroxytryptamine (5-HT), glutamate (Glu), gamma-aminobutyric acid (GABA). ${ }^{*} p<0.01$ when compared with control

cy in depression, even when taking antidepressants and stimulating its release while taking alcohol regularly. Presumably, such a neuroimmune pattern may be a biomarker of the risk of alcohol dependence on the background of depression.

Acknowledgments. The study was supported by the RFBR grant 19-013-00330.

\section{References}

1. Neupane SP. Neuroimmune Interface in the Comorbidity between Alcohol Use Disorder and Major Depression. Front Immunol. 2016;7:655. https://doi.org/10.3389/fimmu.2016.00655. eCollection.

2. Ponizovskiy PA, Gofman AG. Depression in alcohol addicted patients. Zh Nevrol Psikhiatr Im S S Korsakova. 2015;115(7):146-150. https://doi.org/10.17116/jnevro201511571146-150.

3. Masterova E, Bokhan N, Nevidimova T, et al. Role of olfactory reactions, nociception, and immunoendocrine shifts in addictive disorders. American Journal on Addictions. 2017;26(6):640-648.

4. Davydova TV, Vetrile LA, Nevidimova TI, et al. Dopamine, norepinephrine, glutamate antibodies in individual prevention of addiction. European Neuropsychopharmacology. 2017;27(Suppl 4):1078. 